\title{
Sikap Etis Gereja Terhadap Perceraian dan Pernikahan Kembali
}

\author{
Kalis Stevanus \\ Sekolah Tinggi Teologi Tawangmangu \\ kalisstevanus91@gmail.com
}

\section{Abstract}

This paper aims to expose the ethical attitude of the church in dealing with divorce and remarriage in order to be useful as an input for the pastoral ministry in taking handle with those who are going to divorce, has been divorced or who has remarried. By using an analytical descriptive on texts such Matthew 5:32; 19: 9; Mark 10: 11-12; Luke 16:18, and 1 Corinthians 7: 10-11, then the following results are obtained: First, Christian marriage is a monogamous and wholly partnership(indestructible); second, adultery destroys the foundation of marriage, but it should not be a legal reason for divorce; third, divorce never recommended or ordered; fourth, only the separation is allowed, not the divorce due to the goal of reconciliation; fifth, remarriage with the person who has been divorced is a transgression; sixth, the settlement of divorce and remarriage issues that have occurred is the responsibility of the believers communally (whole) to regain those who have separated from their partners.

\begin{abstract}
Abstrak
Artikel ini bertujuan untuk memaparkan sikap etis gereja dalam menyikapi perceraian dan pernikahan kembali agar bermanfaat sebagai bahan masukan bagi pelayanan pastoral gereja dalam menangani anggota warganya yang hendak bercerai, telah bercerai atau yang menikah kembali. Dengan penggunaan metode analisis-deskriptif terhadap teks-teks seperti: Matius 5:32; 19:9; Markus 10:11-12; Lukas 16:18 dan 1 Korintus 7:10-11, maka diperoleh hasil: Pertama, pernikahan Kristen merupakan persekutuan yang bersifat monogami dan seumur hidup (tak terceraikan); kedua, perzinahan merusak fondasi pernikahan, tapi hal itu tidak boleh dijadikan alasan legal untuk bercerai; ketiga, perceraian tidak pernah dianjurkan maupun diperintahkan; keempat, hanya perpisahan yang diperbolehkan, bukan perceraian dengan tujuan untuk rekonsiliasi; kelima, pernikahan kembali dengan orang yang sudah bercerai merupakan pelanggaran (kesalahan); keenam, penyelesaian masalah perceraian dan pernikahan kembali yang telah terjadi adalah tanggung jawab warga gereja secara komunal (keseluruhan) untuk mendapatkan kembali mereka yang telah berpisah dari pasangannya.
\end{abstract}

Article History

Submit:

25 July 2018

Revised:

20 October 2018

Accept:

25 October 2018

Keywords: adultery; death; defection; divorce; ethics; marriage; remarriage; separation

Kata kunci: etika; maut; pembelotan; perceraian; pernikahan pernikahan kembali; pisah; zinah 


\section{Pendahuluan}

Ajaran Kristen melarang untuk bercerai, akan tetapi kenyataan yang tak dapat dipungkiri terjadi kegagalan pernikahan orang-orang Kristen tertentu yang berakhir pada perceraian. Angka perceraian yang terjadi di Indonesia menurut catatan Biro Pusat Statistik pada tahun 2015 mencapai 347.256 kasus $^{1}$, sementara tahun 2016 mencapai 365.633 kasus perceraian. $^{2}$ Kegagalan pernikahan yang diikuti perceraian adalah salah satu dari sekian banyak fakta yang terjadi dalam kehidupan manusia. Kegagalan hubungan suami-isteri, itulah persoalan pertama dan utama terjadinya praktik perceraian. Ruth Schafer dan Freshia Aprilyn Ross menyatakan bahwa kegagalan hubungan suami-isteri, itulah persoalan pertama dan utama, dan realitas itu paling sedikit tidak langsung dipengaruhi ada-tidaknya izin untuk bercerai atau praktik perpisahan. Keinginan untuk bercerai adalah akibat bukan sebab kegagalan relasi itu. ${ }^{3}$ Selain itu perceraian juga diakibatkan oleh bergesernya nilai-nilai masyarakat yang mengarah kepada sekularisme, sehingga nilai-nilai agama terpinggirkan. ${ }^{4}$

Perceraian merupakan masalah yang rumit. Perlu diakui bahwa belum ada kesepakatan atau keseragaman pandangan tentang perceraian di kalangan Kristen sendiri. Diungkapkan oleh Ruth Schafer dan Freshia Aprilyn Ross, bahwa kerumitan itu disebabkan ada teks yang berisi larangan bercerai itu (misal, Mat.5:32; 19:4-9; Mrk.10:6-9, 11-12; Luk.16:18; 1 Kor.7:10-11), ada juga beberapa teks atau bagian ayat yang menentukan kasuskasus yang berfungsi sebagai "pengecualian" untuk praktik perceraian (misal, 1Kor.7:11; 15 16; Mrk.10:11b-12b; Luk.18a; Mat.5:32b; Mat.19:9b). ${ }^{5}$

Karena perbedaan itu dan kerumitan persoalan, juga tidak ada kesepakatan di antara tokoh-tokoh Kristen dalam menyikapi perceraian dan pernikahan kembali. Bahkan, setiap denominasi gereja memiliki pandangannya sendiri. Ada gereja tertentu yang memiliki prinsip dan aturan yang berbeda dalam menanggapi fenomena perceraian dan pernikahan kembali sesuai dengan situasi gereja masing-masing dan berdasarkan interpretasi tertentu dari teksteks Perjanjian Baru. Hal inilah yang menarik perhatian khusus penulis agar soal itu tidak secara asal dalam menangani.

Pembahasan ini terbatas pada pemahaman Kristen tentang pernikahan sebagaimana dinyatakan dalam Alkitab, serta kaitannya dengan kemungkinan perceraian dan pernikahan

\footnotetext{
${ }^{1}$ https://www.bps.go.id/linkTableDinamis/view/id/893, diunduh pada 22 Oktober 2018.

${ }^{2}$ https://www.republika.co.id/berita/dunia-islam/islam-nusantara/18/01/21/p2w4v9396-ratusan-ribukasus-perceraian-terjadi-dalam-setahun, diunduh pada 22 Oktober 2018

${ }^{3}$ Ruth Schafer dan Freshia Aprilyn Ross, Bercerai Boleh atau Tidak? Tafsiran Terhadap Teks-teks Perjanjian Baru (Jakarta: BPK Gunung Mulia, 2017), 1

${ }^{4}$ Sonny Eli Zaluchu, "Mengkritisi Teologi Sekularisasi," KURIOS (Jurnal Teologi dan Pendidikan Agama Kristen) 4, no. 1 (2018): 26-38, www.sttpb.ac.id/e-journal/index.php/kurios.

${ }^{5}$ Schafer, Bercerai Boleh atau Tidak, 10-11
} 
kembali. Bagaimana gereja dapat merumuskan kebijakan serta menjalankannya agar sesuai dengan prinsip alkitabiah? Memang harus diakui, tidak ada jawaban yang mudah atas pertanyaan-pertanyaan itu. Karena perceraian dan pernikahan kembali adalah realitas hidup yang sedang dialami oleh orang-orang Kristen tertentu dan harus ada pegangan/patokan secara biblika yang dimiliki oleh gereja dalam menyikapi masalah tersebut. Sebab gereja merasakan ketegangan di antara pertanggungjawaban panggilan untuk menjadi saksi Kristus bagi dunia dan pertanggungjawaban pastoralnya untuk penyelesaian masalah perceraian dan pernikahan kembali.

\section{Pernikahan Adalah Gagasan Allah}

Ajaran Kristen menekankan bahwa pernikahan adalah gagasan Allah, bukan gagasan manusia. Pernikahan diadakan oleh Allah sendiri pada saat manusia dalam kondisi tidak berdosa. Allah yang membentuk, mengesahkan, dan memuliakan pernikahan. Itu sebabnya John Stott mengatakan bahwa karena pernikahan merupakan aturan penciptaan yang lebih dahulu ada daripada peristiwa kejatuhan, maka hendaknya pernikahan itu dipandang sebagai anugerah Allah kepada seluruh umat manusia. ${ }^{6}$ Erastus Sabdono berpendapat yang sama, bahwa pernikahan adalah gagasan Allah. Allah yang menentukannya sejak semula bahwa laki-laki harus dipersatukan dengan perempuan. Pernikahan sama sekali bukan prakarsa manusia, tetapi prakarsa Allah sendiri. Karena itu, pernikahan harus diakui dan diterima sebagai suatu karunia atau anugerah Allah atas manusia. ${ }^{7}$

Keinginan manusia untuk membentuk sebuah keluarga bukanlah semata-mata keinginannya sendiri, melainkan juga merupakan keinginan Allah. Pernikahan adalah bagian dari rencana Allah bagi umat manusia. Di mana Allah yang berinisiatif menyediakan dan mempertemukan seorang penolong, pasangan hidup bagi Adam,'TUHAN Allah berfirman: 'Tidak baik, kalau manusia itu seorang diri saja. Aku akan menjadikan penolong baginya, yang sepadan dengan dia'" (Kej.2:18). Selanjutnya dikatakan dalam Kejadian 2:21-23 demikian,"Lalu TUHAN Allah membuat manusia itu tidur nyenyak; ketika ia tidur, TUHAN Allah mengambil salah satu rusuk dari padanya, lalu menutup tempat itu dengan daging. Dan dari rusuk yang diambil TUHAN Allah dari manusia itu, dibangun-Nyalah seorang perempuan, lalu dibawa-Nya kepada manusia itu." Allah menambahkan,"Sebab itu laki-laki akan meninggalkan ayahnya dan ibunya dan bersatu dengan isterinya, sehingga keduanya menjadi satu daging" (Kej.2:24). Maksud Tuhan dengan pernikahan itu adalah supaya

\footnotetext{
${ }^{6}$ John Stott, Isu-isu Global (Jakarta: Yayasan Komunikasi Bina Kasih, 2015), 409

${ }^{7}$ Erastus Sabdoono, Perceraian (Jakarta: Rehobot Literature, 2018), 25
} 
pernikahan itu menjadi suatu persekutuan seumur hidup. ${ }^{8}$ Alkitab sangat jelas mengenai lamanya pernikahan, yaitu merupakan komitmen seumur hidup, sampai kematian memisahkan. ${ }^{9}$

Selanjutnya ditegaskan oleh J. Verkuyl bahwa pernikahan adalah suatu peraturan yang ditetapkan oleh Tuhan, di dalam peraturan suci itu diatur-Nya hubungan pria dan wanita. ${ }^{10}$ Peraturan pernikahan yang alkitabiah adalah antara seorang laki-laki dengan seorang perempuan, yaitu pernikahan monogami. Hal ini jelas dari sejak mulanya. Allah menciptakan "laki-laki dan perempuan" (Kej.1:27) dan memerintahkan mereka untuk "beranakcucu dan bertambah banyak" (Kej.1:28). Di dalam Perjanjian Baru, Tuhan Yesus mengutip bagian dari kitab Kejadian yang berkata,'Ia yang menciptakan manusia sejak semula menjadikan mereka laki-laki dan perempuan" (Mat.19:4) Kemudian Tuhan Yesus mengutip bagian tentang meninggalkan ayah dan ibu dan bersatu dengan isterinya (ayat 5). Dengan demikian Tuhan Yesus menegaskan bahwa pernikahan haruslah seorang laki-laki dengan seorang perempuan. Karena itu, pernikahan monogami adalah pernikahan alkitabiah. ${ }^{11}$ Pernikahan Kristen selain sifatnya monogami, juga tak terceraikan. Kedua sifat perkawinan ini harus dipandang sebagai norma moral sekaligus norma hukum. ${ }^{12}$ Juga dikatakan oleh Erastus Sabdono, bahwa pernikahan memiliki sifat hakiki (essentialis properietas) yaitu pernikahan monogami sebagai norma moral pernikahan yang ditetapkan Allah. ${ }^{13}$

Jadi, pernikahan monogami bukan hanya ajaran Perjanjian Lama (Kej.2:24), tetapi juga ajaran Perjanjian Baru (Mat.19:4-5). Monogami ada sejak dari mulanya, ketika Allah menciptakan seorang pria (Adam) dan memberinya hanya satu isteri (Hawa) dan keduanya hidup bersama secara permanen (seumur hidup). Tidak ada oknum lain yang boleh turut hadir dalam ikatan pernikahan tersebut.

Oleh sebab itu, berdasarkan uraian Alkitab di atas, maka dapat dikonklusikan sebagai berikut: Pertama: pernikahan adalah suatu peraturan suci, sebagai lembaga yang ditetapkan oleh Allah. Di dalam peraturan suci itu diatur-Nya hubungan antara pria dan wanita. Tanpa peraturan itu akan timbul kekacauan dan kekalutan kehidupan seksual. Kedua, pernikahan yang ditetapkan oleh Allah (alkitabiah) adalah peraturan monogami, yaitu pernikahan seorang laki-laki dengan seorang wanita saja. Pernikahan di Taman Eden itu digambarkan sebagai

\footnotetext{
${ }^{8}$ Kalis Stevanus, Cekcok Tapi Sudah Cocok (Yogyakarta: Andi, 2014), 1-2

${ }^{9}$ Norman L. Geisler, Etika Kristen: Pilihan dan Isu Kontemporer (Malang: SAAT, 2010), 358

${ }^{10}$ J. Verkuyl, Etika Kristen: Seksuil (Jakarta: BPK Gunung Mulia, 1993), 54-55

${ }^{11}$ Geisler, Etika Kristen: Pilihan dan Isu Kontemporer, 356

${ }^{12}$ Andreas Lumme, "Norma Hukum Agama Katolik Di Bidang Perceraian Dan Konflik Penerapannya Di Pengadilan Bagi Perceraian Suami Istri” Jurnal Hukum Pro Justisia, April 20017, Vol.25 No.2: 91

${ }^{13}$ Sabdoono, Perceraian, 29
} 
suatu penyerahan seorang laki-laki kepada seorang wanita, begitu juga sebaliknya, untuk seumur hidup. Pernikahan monogami adalah pernikahan yang ditetapkan oleh Tuhan. Itu sebabnya di dalam Alkitab monogami dipandang sebagai tuntutan Tuhan dan sebagai pemberian Tuhan. Meskipun di Alkitab ada pernikahan poligami, tetapi itu dipandang sebagai bentuk pernikahan yang merusak maksud Tuhan dengan pernikahan itu. Segala sesuatu yang timbul dari pendurhakaan atau pemberontakan kepada peraturan suci itu (monogami), pasti akan merusak kehidupan manusia sendiri.

\section{Allah Memberkati Pernikahan, tetapi Membenci Perceraian}

Dikatakan dalam Kejadian 1:28,"Allah memberkati mereka, lalu Allah berfirman kepada mereka mereka: 'Beranakcuculah dan bertambah banyak; penuhilah bumi dan taklukkanlah itu, berkuasalah atas ikan-ikan di laut dan burung-burung di udara dan atas segala binatang yang merayap di bumi." Allah merancang suatu pernikahan bahagia yang penuh berkat Allah di dalamnya. Selanjutnya juga dikatakan,'Dan janganlah orang tidak setia terhadap isteri dari masa mudanya. Sebab Aku membenci perceraian, firman TUHAN, Allah Israel... Maka jagalah dirimu dan janganlah berkhianat!” (Mal.2:15-16). Allahlah yang membentuk pernikahan dan memberkatinya. Tetapi Ia tidak punya rancangan perceraian atas apa yang telah dibentuk dan diberkati-Nya. ${ }^{14}$ Maka jelaslah bahwa pernikahan itu harus dihormati dan dipandang sebagai suatu komitmen seumur hidup. "Apa yang telah dipersatukan Allah, tidak boleh diceraikan manusia" (Mrk.10:9). Tuhan telah menghendaki, supaya kedua orang, yang telah dipertemukan dalam suatu perjanjian nikah, tetap bersamasama sampai maut memisahkan. Inilah dasar keteguhan pernikahan Kristen.

Bagaimana dengan hal perceraian? Adakah dasar-dasar untuk perceraian? Apa sebabnya Tuhan menuntut pernikahan untuk seumur hidup? Marilah mencari jawab pertanyaan-pertanyaan itu dengan keterangan dari Alkitab.

Dalam Alkitab, baik dalam Perjanjian Lama maupun Perjanjian Baru, terdapat larangan berzinah dan larangan bercerai. Perceraian lebih jauh dari kehendak Allah. Tidak ada kecaman yang setajam atau dilengkapi dengan argumen teologis yang kuat seperti hal perceraian. Karena perceraian sama sekali menghancurkan pernikahan. Ada serangan yang tidak mengenal kompromi terhadap perceraian, yang memuncak dengan kecaman yang terang-terangan seperti dinyatakan dalam Maleakhi 2:13-16 "Aku membenci perceraian, firman TUHAN, Allah Israel." ${ }^{\prime 5}$ Jelaslah bahwa Allah tidak merancangkan perceraian. Allah

\footnotetext{
${ }^{14}$ Stevanus, Cekcok Tapi Sudah Cocok, 3

${ }^{15}$ Christopher Wright, Hidup sebagai Umat Allah: Etika Perjanjian Lama (Jakarta: BPK Gunung Mulia, 1995), 182
} 
menciptakan satu pria untuk satu wanita dan menghendakinya agar mereka berdua memelihara janji mereka sampai maut memisahkan mereka. Dengan kata lain, perceraian bukanlah rancangan Allah atas pernikahan.

Seperti yang diungkapkan oleh Henk ten Napel, bahwa keberadaan manusia sebagai laki-laki atau perempuan serta perbedaan kelamin itu adalah sesuai dengan kehendak Allah dalam penciptaan-Nya. Sehubungan dengan ini, maka laki-laki dan perempuan yang dipersatukan melalui pernikahan, dipersatukan oleh Allah sendiri. Pencipta sendiri campur tangan dalam hal pernikahan. Persatuan yang dikehendaki Allah disebut dengan suatu istilah yang diambil dari Perjanjian Lama: "menjadi satu daging" (Mrk.10:8) atau "bersatu" (Mat.19:5). Istilah ini menunjuk kepada persatuan personal yang penuh dan persekutuan hidup. Di mana di dalamnya tercakup kesetiaan dan kelanggengan. ${ }^{16}$ Sebab itu, kegagalan hidup pernikahan selalu merupakan tragedi. Tentu saja, hal itu bertentangan dengan maksud dan kehendak Allah dalam membentuk pernikahan. Kenyataannya ada pernikahan yang gagal dan berakhir pada perceraian.

Selanjutnya dikatakan di dalam Firman ketujuh yang berbunyi: "Jangan berzinah" (Kel.20:14). Di dalam hukum Taurat Musa, larangan itu diuraikan lebih lanjut dengan berbagai cara, dengan apa yang disebut "undang-undang nikah" (U1.22:13-30), bahwa perzinahan harus dihukum dengan hukuman mati (dirajam, dilempari batu sampai mati). Sebab perbuatan zinah dipandang sebagai semacam pembunuhan. ${ }^{17} \mathrm{~J}$. Verkuyl mengatakan bahwa perzinahan dan perceraian itu merusakkan kasih kepada Tuhan. Itu adalah dosa, yang pertama-tama melanggar hukum Tuhan dan melawan kasih-Nya. Perzinahan dan perceraian bukan saja dosa terhadap Tuhan, tetapi juga dosa terhadap kasih kepada sesame-manusia. Selain itu, perzinahan dan perceraian juga merusakkan kasih kepada anak-anak. Itu merupakan suatu tamparan bagi anak-anak yang akibatnya tidak dapat diatasinya seumur hidupnya. ${ }^{18}$ Oleh sebab itu, perceraian harus dicegah, ada usaha untuk rekonsiliasi kedua pihak melalui pelayanan pastoral sehingga pernikahan tetap terjaga sampai maut memisahkan mereka. Perceraian tidak direkomendasikan karena alasan apa pun.

\section{Metodologi}

Artikel ini merupakan penelitian fenomonologi yang menggunakan metode deskriptif analatik. Penulis mendeskripsikan konsep pernikahan, perceraian dan pernikahan kembali

\footnotetext{
${ }^{16}$ Henk ten Napel, Jalan yang Lebih Utama Lagi: Etika Perjanjian Baru (Jakarta: BPK Gunung Mulia, 20120, 44-45

${ }^{17}$ Verkuyl, Etika Kristen: Seksuil, 109

${ }^{18}$ Ibid., 110-111
} 
menurut pandangan Alkitab, baik dalam Perjanjian Lama maupun Perjanjian Baru. Selain itu, penulis juga menggunakan teori-teori beberapa teolog tentang segala hal yang berkaitan dengan perceraian. Selanjutnya konsep-konsep tersebut dianalisis dengan pendekatan norma dan etis-teologis, sehingga diperoleh landasan biblikal untuk bersikap bagi gereja terhadap kasus-kasus pastoral yang sedang marak, yakni perceraian. Penting kita memahami mengenai rumusan pernikahan, perzinahan, perceraian dan pernikahan kembali di dalam Alkitab, baik dalam Perjanjian Lama maupun Perjanjian Baru, yang menghasilkan prinsip untuk dapat digunakan dalam konteks masa kini.

\section{Pandangan Perjanjian Lama}

Ulangan 24:1-4 merupakan satu-satunya bagian dalam Perjanjian Lama yang berbicara tentang isu perceraian dan pernikahan kembali. John Stott memberikan tiga poin khusus yang perlu diklarifikasi tentang hukum tersebut. ${ }^{19}$

Pertama, menikahi kembali mantan pasangan. Apakah yang ditekankan dan yang menjadi tujuan dari bagian Alkitab ini? John Stott menegaskan, bahwa perceraian tidak dituntutnya, atau direkomendasikannya, atau bahkan diizinkannya. Menurutnya, perhatian utamanya sama sekali bukan mengenai perceraian, atau bahkan bukan juga sertifikat perceraian. Diduga bahwa hukum ini dimaksudkan untuk melindungi perempuan dari mantan suami yang sikapnya berubah-ubah dan mungkin kejam. Peraturan hukum ini tidak berarti menyetujui perceraian; yang dikatakan ialah apabila seorang laki-laki menceraikan isterinya, dan kalau ia memberi surat cerai dan setelah itu perempuan itu menikah lagi, lalu apabila suami keduanya tidak menyukainya atau menceraikannya ataupun meninggal dunia, mereka tidak boleh menikah kembali.

Kedua, bercerai karena tidak senonoh. Sekalipun perceraian tidak dianjurkan, tetapi kalau itu terjadi, maka alasan yang menjadi dasarnya ialah bahwa suami mendapati isterinya bertindak yang "tidak senonoh." Karena istilah ini kurang jelas, maka muncullah beberapa interpretasi. Dalam Perjanjian Baru, ada dua pandangan yang bertentangan, yaitu tafsiran mazhab Rabi Shammai dan mazhab Rabi Hillel. Menurut Rabi Shammai, menafsirkan istilah "tidak senonoh" secara sempit, sehingga hanya menunjuk kepada dosa-dosa yang nyata seperti perzinahan dan lain-lain. ${ }^{20}$

Menurut Ruth Schafer dan Freshia Aprilyn Ross, tafsiran dan praktik mazhab Hillel lebih sering diterapkan pada abad pertama daripada tafsiran dan praktik mazhab Shammai.

\footnotetext{
${ }^{19}$ Stott, Isu-isu Global , 418-420

${ }^{20}$ Napel, Jalan yang Lebih Utama Lagi: Etika Perjanjian Baru, 44
} 
Pada akhirnya, pernikahan dapat dianggap seolah-olah sebagai hal yang sepele, yang dengan mudah dibubarkan sekehendak hati laki-laki. ${ }^{21}$ Orang-orang yang hidup dalam budaya-budaya penyembah berhala menganggap perzinahan sebagai sebuah alasan legal untuk bercerai. ${ }^{22}$ Begitu pun kedua aliran Yahudi, baik Hillel maupun Shammai, hal itu tidak diperdebatkan. Kendatipun terdapat perbedaan interpretasi antara mazhab-mazhab itu, namun semuanya sepakat, bahwa suami mempunyai hak untuk menceraikan isterinya secara legal, yaitu dengan menyerahkan supucuk surat cerai kepada isterinya.

Ketiga, kebebasan perempuan menikah kembali. Apabila perceraian diizinkan, maka tentu pernikahan kembali pun diperbolehkan. Ulangan 24:1-4 mengandaikan bahwa sekali perempuan tersebut sudah diceraikan, maka perempuan itu bebas menikah kembali, walaupun dia merupakan pihak yang bersalah karena "didapatinya yang tidak senonoh padanya". Semua budaya kuno waktu itu memahami bahwa perceraian sekaligus merupakan izin untuk menikah kembali. $^{23}$

Setelah melalui pembacaan yang saksama dari teks Ulangan 24 ini, kisah seorang perempuan yang diceraikan oleh suami pertamanya, menikah dengan suami yang kedua dan juga diceraikan olehnya. Sebenarnya isu utamanya ialah apakah ia dapat menikahi suami yang pertama kembali? Jawabannya adalah tidak, karena ia "telah dicemarkan" (ayat.4). Dengan demikian, teks ini tidak boleh dijadikan dasar atau acuan pengesahan bagi praktik perceraian dan pernikahan kembali. Teks ini dimaksudkan untuk melindungi perempuan yang pada zaman itu tidak memiliki kesamaan hak dengan laki-laki agar tidak diceraikan sesuka hatinya.

\section{Pandangan Perjanjian Baru}

Dalam khotbah Tuhan Yesus di bukit, Ia berbicara mengenai perceraian di dalam Matius 5:31, "Telah difirmankan juga: Siapa yang menceraikan isterinya harus memberi surat cerai kepadanya”. Selanjutnya dikatakan Tuhan Yesus,'Tetapi Aku berkata kepadamu: Setiap orang yang menceraikan isterinya kecuali karena zinah, ia menjadikan isterinya berzinah; dan siapa yang kawin dengan perempuan yang diceraikan, ia berbuat zinah” (Mat.5:32).

Dalam Matius 19:1-9 Tuhan Yesus juga berbicara mengenai perceraian, tetapi hal tersebut berbeda dengan pernyataan di Matius 5:31-32. Dalam Matius 19:1-9 Tuhan Yesus berbicara tentang perceraian tetapi hal tersebut sebagai respon terhadap pertanyaan orangorang Farisi mengenai perceraian. Sedangkan di Matius 5:31-32 bukan karena menjawab pertanyaan, tetapi Tuhan Yesus sengaja mengetengahkan hal ini, sebab hal perceraian

\footnotetext{
${ }^{21}$ Schafer dan Ross, Bercerai Boleh atau Tidak? Tafsiran Terhadap Teks-teks Perjanjian Baru, 43-44

${ }^{22}$ Stott, Isu-isu Global , 424

${ }^{23}$ Ibid.,428
} 
memang masalah umum yang terjadi dalam kehidupan masyarakat sejak zaman dahulu. Tentang perceraian ini melengkapi khotbah-Nya di bukit, ketika Ia meletakkan landasan hidup orang Kristen dalam menghadapi dan menjalani hidup yang dikenal sebagai golden rule (undang-undang emas). ${ }^{24}$

Menurut Glen H. Stassen dan David P. Gushee, pemberian surat cerai dalam masyarakat Yahudi pada waktu itu tampaknya untuk memberikan suatu perlindungan minimal bagi perempuan yang ditinggalkan dalam sebuah masyarakat patriarchal. Dengan demikian, hal ini konsisten dengan hukum-hukum Perjanjian Lama lainnya yang dimaksudkan untuk membela kepentingan orang-orang yang lemah. Jika perceraian dipandang sebagai hal yang rutin, perempuan berada dalam risiko yang besar. ${ }^{25}$

Apa yang disampaikan oleh Tuhan Yesus tentang pernikahan dan perceraian diberikan dalam rangka menangapi suatu pertanyaan dari kaum Farisi untuk "mencobai Dia" dengan bertanya kepada-Nya: "Apakah seorang suami diperbolehkan menceraikan isterinya?" (Mrk.10:2). Matius menerangkan lebih lanjut pertanyaan tersebut: "Apakah diperbolehkan orang menceraikan isterinya dengan alasan apa saja?" (Mat.19:3).

John Stott menyatakan mungkin alasan di balik pertanyaan mereka itu adalah skandal umum Herodias, yang meninggalkan suaminya Filipus untuk menikah dengan Raja Herodes Antipas. Yohanes Pembaptis dengan berani menegur hubungan mereka sebagai hal yang "tidak boleh" (Mrk.6:17-29), dan sebagai akibatnya ia dipenjarakan. Apakah Tuhan Yesus akan juga berbicara terus-terang seperti Yohanes Pembaptis itu? Yang jelas orang Farisi itu ingin menyangkutkan Tuhan Yesus ke dalam debat Rabi Shammai-Hillel. Oleh karena itu, penekanan dalam pertanyaan mereka adalah pada "alasan" yang membenarkan perceraian. ${ }^{26}$

Menurut Glen H. Stassen dan David P. Gushee, sebenarnya pemahaman tentang pernikahan inilah yang hendak diangkat oleh Tuhan Yesus di hadapan para pendengar-Nya. Ia mengesampingkan pertanyaan legalistic yang hendak mereka tanyakan: Kapan diperbolehkan untuk bercerai? Singkatnya, Tuhan Yesus berkata kepada mereka: Lakukan kehendak Allah untuk pernikahan dan berhenti bertanya kapan diperbolehkan untuk melakukan yang kurang dari itu. $^{27}$

Tentang surat cerai itu, Tuhan Yesus mengalihkan perhatian para pendengar-Nya untuk kembali kepada maksud semula Allah bagi pernikahan. Mendengar jawaban Tuhan

\footnotetext{
${ }^{24}$ Sabdoono, 3-4

${ }^{25}$ Glen H. Stassen dan David P. Gushee, Etika Kerajaan : Mengikut Yesus dalam Konteks Masa Kini (Surabaya: Momentum, 2013), 357

${ }^{26}$ Sott, Isu-isu Global, 420-421

${ }^{27}$ Stassen dan Gushee, Etika Kerajaan : Mengikut Yesus dalam Konteks Masa Kini, 355
} 
Yesus yang mengarahkan pendengar-Nya kepada ketetapan Allah sejak semula, yaitu sebelum manusia jatuh ke dalam dosa, mereka tidak puas. Kemudian, mereka mengajukan argumentasi untuk mendebat-Nya,"Jika demikian, apakah sebabnya Musa memerintahkan untuk memberikan surat cerai?" (Mat.19:7). Argumentasi ini berisi usaha untuk membenturkan tindakan Musa yang diakui sebagai guru orang Yahudi, yaitu mengizinkan perceraian dengan surat cerai, dengan pernyataan Tuhan Yesus yang tidak membuka peluang untuk bercerai. Argumentasi orang-orang Farisi itu, bisa juga merupakan usaha untuk memperoleh pembenaran untuk menceraikan isteri, kemudian menikah lagi demi memuaskan nafsu tanpa merasa bersalah. Dengan jelas dan tegas, Tuhan Yesus menjawab mereka,"Karena ketegaran hatimu Musa mengizinkan kamu menceraikan isterimu, tetapi sejak semula tidaklah demikian" (Mat.19:8).

\section{Pembahasan}

Pada bagian ini membahas secara khusus konsep Perjanjian Baru tentang pernikahan, perzinahan, perceraian dan pernikahan kembali menurut ajaran Yesus dan Paulus.

\section{Menurut Ajaran Yesus}

Ada beberapa poin yang ditekankan dalam pengajaran Yesus berkaitan dengan pernikahan, perceraian dan pernikahan kembali.

\section{Pernikahan itu Bersifat Tetap atau Seumur Hidup}

Ada hal penting untuk diperhatikan bahwa Tuhan Yesus tidak memberikan jawaban langsung terhadap pertanyaan orang Farisi tentang perceraian. Malahan Tuhan Yesus berbicara kepada mereka mengenai pernikahan. Tuhan Yesus merujuk pada Perjanjian Lama (Kej. 1 dan 2), serta menyatakan tidak percaya kalau mereka belum membaca teks-teks tersebut. Sebaliknya, Tuhan Yesus minta mereka memerhatikan dua fakta bahwa seksualitas manusia merupakan karya ilahi dan bahwa pernikahan manusia merupakan rancangan dan pengaturan ilahi. Tuhan Yesus menggabungkan kedua ayat (Kej.1:27 dan 2:24) serta mengatakan bahwa Allah adalah yang mengadakan kedua teks tersebut karena Pencipta yang “sejak semula ...membuat mereka laki-laki dan perempuan" juga mengatakan,"Sebab itu lakilaki akan meninggalkan ayah dan ibunya dan bersatu dengan isterinya, sehingga keduanya itu menjadi satu daging." Lalu Tuhan Yesus menambahkan serta menegaskan penjelasan-Nya sendiri,"mereka bukan dua lagi, melainkan satu. Dan "Karena itu" kata-Nya menambahkan larangan-Nya sendiri,"apa yang telah dipersatukan Allah, tidak boleh diceraikan manusia" (Mat.19:6; Mrk.10:9). Ajaran Tuhan Yesus jelas, bahwa ikatan pernikahan bukanlah 
pengalaman manusiawi yang naik turun ("Aku mencintaimu, Aku tidak cinta kepadamu”), tetapi kehendak Allah (mereka "menjadi satu daging"). ${ }^{28}$

Hal itu juga diakui oleh Noeroel Moearifah dan Mukayat Al-Amin, bahwa perkawinan dalam kekristenan bukanlah perkawinan sekedar suka sama suka atau saling mencintai belaka, akan tetapi perkawinan itu juga cerminan dari gambar Allah, ada keterlibatan Allah, ada persekutuan dengan Allah, hanya maut yang dapat memisahkan. ${ }^{29}$ Wayde I. Goodall dan Rosalyn R. Goodall mendefinisikan pernikahan adalah komitmen public antara seorang lakilaki dan perempuan untuk menjadi satu dan tetap saling setia hingga ajal. ${ }^{30}$ Dengan demikian, pernikahan Kristen adalah persekutuan hidup antara seorang laki-laki dan seorang perempuan atas dasar cinta-kasih yang seutuhnya (lahir dan batin) yang sifatnya seumur hidup, kecuali maut yang memisahkan.

\section{Perceraian adalah Perkara Perzinahan}

Tuhan Yesus mengklasifikasikan perceraian sebagai perkara “perzinahan”. Ia berkata: "Setiap orang yang menceraikan isterinya kecuali karena zinah". Tuhan Yesus tidak menyangkal, bahwa ada hal-hal khusus yang menyebabkan pernikahan tidak tertahan lagi, yakni jika terjadi perbuatan zinah. Tetapi janganlah hal itu disalahpahami. Tuhan Yesus sekali-kali tidak bermaksud mengatakan, bahwa perbuatan zinah selalu dapat menjadi dasar atau alasan untuk bercerai. ${ }^{31}$ Dengan sangat jelas dikatakan oleh Glen H. Stassen dan David P. Gushee bahwa di dalam Markus - seperti juga dalam Lukas-tidak dituliskan klausa pengecualiaan karena "zinah" itu berarti tidak ada perceraian yang dapat dibenarkan. ${ }^{32}$

Selanjutnya dijelaskan oleh Norman L. Geisler, berkenaan dengan pertanyaan yang diajukan kepada Tuhan Yesus tentang perceraian yang di dalam Markus 10:1-9, Dia tidak memberikan perkecualiaan. Sikap yang sama ini ditegaskan oleh Tuhan Yesus di dalam Lukas 16:8. Yang disebut perkecualiaan dalam Matius 19:1-9 band Mat. 5:32 menjelaskan bukan tentang perceraian karena perzinahan melainkan pembatalan karena "percabulan" sebelum pernikahan (ayat 9). Menurutnya, hal ini sesuai dengan hukum Yahudi tentang percabulan sebelum pernikahan menjadi dasar dibatalkannya pernikahan. Menurut hukum Yahudi, istilah suami juga berarti pria yang sudah bertunangan (Ul.22:13-19; Mat.1:18-25). ${ }^{33}$ Para penganut sikap yang mengizinkan perceraian hanya karena perzinahan mengambil ayat

\footnotetext{
${ }^{28}$ Ibid., 422

${ }^{29}$ Noeroel Moearifah dan Mukayat Al-Amin, "Perkawinan Menurut Islam dan Protestan” Jurnal ALHikmah, Vol. 1, No. 2, 2015:6

${ }^{30}$ Wayde I. Goodall dan Rosalyn R. Goodall, Marriage \& Family (Malang: Gandum Mas, 2010), 16

${ }^{31}$ Verkuyl, Etika Kristen: Seksuil, 114

${ }^{32}$ Stassen dan Gushee, Etika Kerajaan : Mengikut Yesus dalam Konteks Masa Kini, 351

${ }^{33}$ Norman L. Geisler, Norman. Etika Kristen: Pilihan dan Isu Kontemporer (Malang: SAAT, 2010), 361
} 
ini untuk menunjuk pada ketidaksetiaan seksual setelah pernikahan oleh salah satu pasangan. Menurut Geisler, interpretasi demikian ini tidak didukung oleh baik konteks, bagian-bagian yang parallel, maupun kebiasaan-kebiasaan pada zaman itu. ${ }^{34}$

Sedangkan menurut J. Verkuyl, yang dimaksudkan Tuhan Yesus zinah di sini ialah suatu keadaan, di mana isteri atau suami jatuh ke dalam dosa, tidak secara insidentil (kebetulan), tetapi si isteri atau si suami hidup dan dengan tetap hidup dalam dosa zinah. Di situlah hancurnya dasar atau fondasi pernikahan. Di situlah pernikahan telah rusak sama sekali, dan jika sudah demikian keadaannya (tidak dapat diperbaiki kembali), perceraian diijinkan. Sebab pada hakikatnya pernikahan itu tidak ada lagi. ${ }^{35}$ Erastus Sabdono juga berpendapat yang sama, bahwa perzinahan di Matius 19:9 adalah "porneia atau pornos" yakni perzinahan yang sampai taraf merusak hakikat pernikahan, sehingga tidak dapat dipulihkan kembali. Olehnya, Tuhan Yesus terpaksa (necessity evil) mengizinkan perceraian. Namun demikian bukan berarti Tuhan Yesus menghendaki perceraian. Hendaknya Matius 19:9 tidak dijadikan alasan melakukan perceraian. ${ }^{36}$

Sebenarnya perkataan Tuhan Yesus mempertajam apa yang terdapat dalam Hukum Taurat tentang perceraian dan perzinahan. Menurut-Nya, seorang suami yang menceraikan istrinya "berzinah" dan dengan demikian melanggar hukum Allah yang asasi karena perintah “jangan berzinah" tertuang dalam Dasa Titah (band. Kel.20:14; U1.5:18). ${ }^{37}$ Hal itu menegaskan bahwa pelakunya dikatakan "berzinah".

\section{Ketentuan Musa tentang Perceraian}

Tuhan Yesus menyatakan bahwa ketentuan Musa tentang perceraian merupakan pengurangan tuntutan yang diizinkan karena adanya dosa manusia. Orang Farisi menanggapi kutipan dari Kejadian 2:24 dengan mengajukan pertanyaan kedua: "Jika demikian, apakah sebabnya Musa memerintahkan untuk memberikan surat cerai jika orang menceraikan isterinya?" Tuhan Yesus menjawab, "Karena kekerasan hatimu Musa mengizinkan kamu menceraikan isterimu, tetapi sejak semula tidaklah demikian.” Dengan demikian, apa yang mereka istilahkan dengan "perintah", Tuhan Yesus menyebutnya "izin", dan itu pun izin yang direlakan dengan sedih hati, yang diberikan karena kekerasan hati manusia dan bukan kehendak ilahi. ${ }^{38}$ Karena Tuhan Yesus mengacu pada ketetapan Musa sebagai izin bagi dosa manusia, maka tentu tidak mungkin hal itu dijadikan petunjuk bahwa Pencipta menyetujui

\footnotetext{
${ }^{34}$ Ibid., 368

${ }^{35}$ Verkuyl, Etika Kristen: Seksuil, 114

${ }^{36}$ Sabdoono, Perceraian, 139

${ }^{37}$ Schafer dan Ross, Bercerai Boleh atau Tidak? Tafsiran Terhadap Teks-teks Perjanjian Baru, 68

${ }^{38}$ Stott, Isu-isu Global, 422-423
} 
perceraian. Dengan kata lain, tidak boleh ditafsirkan sebagai persetujuan-Nya untuk praktik perceraian.

John Stott menegaskan, bahwa perceraian sebagaimana diizinkan oleh Allah bertentangan dengan pernikahan sebagaimana diadakan oleh Allah "sejak semula". Menurutnya, kesesatan para rabi terletak pada realitas bahwa mereka mengabaikan perbedaan antara kehendak Allah (Kej.1 dan 2) dan ketentuan hukum-Nya bagi kondisi manusia berdosa $(\mathrm{U} 1.24){ }^{39}$

\section{Pernikahan Kembali Setelah Bercerai}

Tuhan Yesus menamakan pernikahan kembali setelah bercerai sebagai "zinah". Bercerai supaya dapat menikah dengan perempuan lain tidak diterima oleh Tuhan Yesus dalam Injil Lukas, bahkan dikategorikan-Nya sebagai dosa "zinah". Semestinya ini dipahami sebagai aturan yang meneguhkan pengajaran Perjanjian Lama. Dengan jelas dalam Injil Lukas, Tuhan Yesus tidak memberikan perkecualiaan untuk perceraian melainkan berkata secara tegas,"Setiap orang yang menceraikan isterinya, lalu kawin dengan perempuan lain, ia berbuat zinah; dan barangsiapa kawin dengan perempuan yang diceraikan suaminya, ia berbuat zinah" (Luk.16:18).

Menurut John Stott berdasarkan ajaran Tuhan Yesus dari Injil-injil Sinoptik, dan untuk sementara mengesampingkan anak kalimat pengecualian, maka dapat disimpulkan bahwa perceraian dan pernikahan kembali adalah zinah. Konsekuensi logis dari dosa tersebut secara terang-terangan diperlihatkan oleh kata-kata Tuhan Yesus sebagai berikut: seorang suami (dan tentu seorang isteri juga) menceraikan isterinya, dan kemudian menikah lagi, baik dia sendiri melakukan perzinahan (Mat.19:9; Mrk.10:11; Luk.16:18) maupun karena asumsinya adalah bahwa perempuan yang diceraikannya juga menikah kembali, maka dia juga menyebabkan perempuan itu berbuat zinah (Mat.5:32); Mrk.10:12). Selanjutnya, seorang laki-laki (dan tentu seorang perempuan juga) yang menikahi seorang janda-cerai berbuat zinah juga (Mat.5:32; Luk.16:18). ${ }^{40}$

Pandangan Tuhan Yesus ini beranggapan bahwa tak ada alasan apa pun bagi perceraian. Dengan demikian, bagi Tuhan Yesus, perceraian dan pernikahan kembali diidentikkan dengan perzinahan, karena Tuhan Yesus tidak menganjurkan perceraian dan pernikahan kembali. Hanya maut yang dapat memisahkan seseorang dari pasangannya dan menikah kembali. Hanya maut saja yang bisa dijadikan alasan sah untuk pernikahan kembali.

\footnotetext{
${ }^{39}$ Ibid., 423

${ }^{40}$ Ibid.
} 
Tuhan Yesus menyatakan perceraian karena zinah (porneia) ${ }^{41}$ diizinkan, tetapi bukan diperintahkan. Ia tidak mengajarkan bahwa pihak yang tidak bersalah harus menceraikan pasangan yang tidak setia sebab perzinahan dengan sendirinya membubarkan pernikahan. Sebaliknya, Ia menekankan bahwa pernikahan sebagai tujuan Allah dan tidak sekali-kali mendorong atau menganjurkan perceraian dengan memakai alasan perzinahan (porneia) tersebut. Ia mengingatkan orang-orang pada saat itu akan norma penciptaan dan tujuan Allah yang tidak berubah. ${ }^{42}$

Dengan penjelasan ini diperoleh kesimpulan bahwa perkataan Tuhan Yesus ini tidak bermaksud melegalisir perceraian dengan alasan zinah (porneia), apalagi menganjurkan perceraian kalau pasangannya melakukan zinah. Karena tidak ada dasar atau alasan bagi perceraian, maka perceraian adalah dosa dan pernikahan kembali dengan orang yang sudah bercerai (pria) dan yang diceraikan (wanita) merupakan pelanggaran (kesalahan), karena mereka akan hidup dalam dosa (Mat.5:32). Jadi, dalam pandangan Allah orang yang "diceraikan" itu masih menikah. Karena itu, hidup bersama dengan orang lain berarti perzinahan, karena ini berarti hubungan seksual dengan orang yang sudah menikah.

Jika begitu, jelas sebab isteri yang telah diceraikan tidak boleh dinikahi seorang lakilaki lain. Jika dinikahi, suami barunya itu dianggap melanggar hubungan nikah yang lebih dahulu. Sekaligus ia membatalkan "kemungkinan" untuk perdamaian atau rekonsiliasi di antara kedua pasangan pernikahan lebih dahulu.

\section{Menurut Paulus}

Pangajaran Paulus menyangkut kasus perceraian seperti tertuang pada 1 Korintus 7:10-16. Paulus menegaskan kembali larangan Tuhan Yesus tentang perceraian, pada ayat 10 dan 11, seperti yang diajarkannya di dalam Roma 7:1-3, dan sebagaimana pengajaran Tuhan yang dicatat oleh Markus dan Lukas, larangan bercerai dinyatakan secara jelas dan tegas bahwa "Seorang isteri tidak boleh menceraikan suamiunya ... dan seorang suami tidak boleh menceraikan isterinya." 43 Pengajaran Paulus mengenai perceraian dalam ayat ini mengatasnamakan Tuhan. Tegas sekali Paulus menyatakan,’bukan aku, tetapi Tuhan

\footnotetext{
${ }^{41}$ Definisi pornei adalah zinah atau ketidaksetiaan dalam pernikahan dan mencakup semua jenis hubungan seksual yang melanggar hukum (John Stott, 425). Sedangkan menurut Erastus Sabdono, perzinahan (na'af, bdk. U1.20:14) meliputi hubungan seks antara laki-laki dan perempuan yang masing-masing atau salah satu terikat pernikahan dengan pasangan lain. Kata "zinah" sering juga digunakan untuk menunjuk ketidaksetiaan umat terhadap Allah (Mzm.73:27). Sedangkan kata Porneia menunjuk perilaku seseorang yang sudah meninggalkan hakikat pernikahan. Jadi porneia adalah perzinahan yang sampai taraf merusak hakikat pernikahan. Sampai tingkat tindakan seperti ini Tuhan Yesus terpaksa "mentolerir" (Mat.19:9). "Keterpaksaan" ini bukan berarti Tuhan Yesus menghendaki perceraian. (Erastus Sabdono, 139).

${ }^{42}$ Stott, Isu-isu Global, 425-426

${ }^{43}$ Ibid.
} 
perintahkan" (ayat 10). Jadi Paulus tidak mentoleris praktik perceraian. Perceraian dipandangnya sebagai pelanggaran terhadap ketetapan Tuhan. Lalu ia menasihati jemaat Korintus,”... janganlah engkau mengusahakan perceraian!" (1 Kor.7:27). ${ }^{44}$

Pada ayat 11, Paulus menambahkan sisipan penting yang menyatakan bahwa jika seorang isteri "bercerai" dari suaminya, dia harus tetap tidak menikah atau berdamai dengan suaminya. Paulus lebih menekankan panggilan Kristennya adalah untuk tetap tidak menikah atau rekonsiliasi dengan suaminya, tetapi tidak menikah kembali. ${ }^{45}$

Menurut Paulus perceraian diperbolehkan kecuali alasan "pembelotan" di mana orang Kristen ditinggalkan oleh pasangan yang tidak seiman (non-Kristen). Hal yang dibahas Paulus di sini mengenai situasi yang muncul ketika dua orang non-Kristen menikah, yang salah satunya kemudian bertobat menjadi Kristen. Haruskah pasangan Kristen menceraikan yang tidak Kristen? Jawaban Paulus sangat jelas, apabila pasangan yang tidak Kristen "mau hidup bersama-sama” dengan yang Kristen, maka yang Kristen tidak boleh menceraikan. Alasannya, pasangan yang tidak percaya "dikuduskan"46 melalui pasangannya yang percaya (Kristen), demikian pula anak-anak mereka. Dan juga alasannya, bahwa Allah memanggil orang Kristen untuk hidup dalam damai sejahtera. Dengan demikian, Paulus menegaskan bahwa apabila pihak yang tidak Kristen menolak untuk tinggal, maka yang pihak Kristen "tidak terikat" artinya terikat untuk mempertahankan kebersamaan dengan pasangannya, bahkan terikat pada pernikahan itu sendiri.

Kebebasan orang Kristen yang dimaksudkan Paulus bukan diakibatkan oleh pertobatan dirinya, melainkan lebih karena keadaan pasangannya yang tidak bertobat dan ketidaksediaan pasangannya untuk tetap tinggal. Karena itu, yang pihak Kristen tidak boleh mencoba melepaskan diri. ${ }^{47}$ Inisiatif tidak datang dari pihak orang Kristen. Dengan amat jelas dikatakan Paulus, jika pasangan yang tidak Kristen bersedia tetap tinggal-hidup bersama,"janganlah saudara itu menceraikan dia" dan "janganlah dia (perempuan) menceraikan laki-laki itu" (ayat 12-13). Sebaliknya, apabila pasangan yang tidak Kristen bersikeras untuk melepaskan diri, "biarlah dia pergi" (ayat 15). ${ }^{48}$

Pandangan John Stott di atas, juga didukung oleh J. Verkuyl berkaitan dengan perceraian di dalam 1 Korintus 7:15, yaitu suatu pernikahan, yang salah satu dari kedua pihak

\footnotetext{
${ }^{44}$ Sabdono, Perceraian, 145

${ }^{45}$ Stott, Isu-isu Global, 426

${ }^{46}$ Pengudusan yang dimaksud Paulus bukan pengudusan dalam pengertian transformasi karakter menjadi serupa dengan Kristus. John Murray menjelaskannya sebagai pengudusan yang menyangkut hak istimewa (privilege), hubungan (connection) dan relasi (relationship). Lihat John Stott, 428

${ }^{47}$ Stott, Isu-isu Global, 428-429

${ }^{48}$ Ibid., 430
} 
telah bertobat dan menjadi orang Kristen. Jika pihak yang lain tidak (atau belum) memeluk agama Kristen, dan tidak merintangi pihak kesatu yang telah menjadi orang Kristen itu, maka haruslah kedua pihak tetap bersatu di dalam pernikahan mereka. Tetapi jika pihak yang bukan Kristen itu tidak mau lagi hidup bersama dengan suami atau isterinya, karena suami atau isteri itu telah menjadi Kristen, maka tidak ada larangan lagi untuk bercerai. Tetapi inisiatif untuk bercerai itu janganlah sekali-kali datang dari pihak yang sudah menjadi Kristen. ${ }^{49}$

Perceraian akibat ditinggalkan atau meninggalkan dalam arti umum atau lari dari kenyataan, bukanlah pilihan kristiani. Orang Kristen harus mendengarkan seruan-Nya: "Apa yang telah dipersatukan Allah, tidak boleh diceraikan manusia.” Dengan demikian, soal perceraian, Paulus menambahkan ketentuan pengecualian yang diizinkan, yaitu dalam keadaan "ditinggalkan" pasangan atau ketidaksediaan pasangannya untuk tetap tinggal bersama. Perceraian yang demikian merupakan keinginan dari pasangan yang tidak seiman sehingga kegagalan pernikahan itu bukan akibat kesalahan pasangan yang Kristen. Juga oleh sebab itu, pasangan yang Kristen memiliki pilihan untuk melanjutkan kehidupan rumah tangga yang baru dengan menikah lagi. ${ }^{50}$

Perceraian semacam ini tidak dinyatakan sebagai pelanggaran terhadap hukum Tuhan. Paulus mengizinkan perceraian sepasang suami isteri oleh sebab salah satu pihak tidak percaya (menerima Injil), mereka diberi kelonggaran untuk bercerai, yaitu bila pihak yang tidak percaya menghendakinya. Alasannya jelas, yaitu demi kelangsungan kehidupan iman Kristennya tidak luntur. Kemungkinan lain alasan Paulus mengizinkan perceraian pernikahan tidak seiman adalah factor kesatuan dan nilai pernikahan itu sendiri bahwa pernikahan orang percaya dengan orang tidak percaya adalah pernikahan yang tidak sesuai tatanan Tuhan. Paulus memandang pernikahan campur adalah pernikahan yang tidak dikehendaki Tuhan. Sebagai perbandingan patur dicatat, bhawa kepada pasangan suami isteri yang seiman, Paulus tidak pernah memberi peluang untuk bercerai. Paulus konsisten dengan sikapnya dalam menentang atau melarang perceraian (1 Kor.7:10-11, 27).

Untuk menyimpulkan soal perceraian dan pernikahan kembali dalam tulisan ini, Perjanjian Baru merupakan sumber utama karena teks ini yang paling berpengaruh untuk aturan gereja masa kini. Karena Alkitab memandang pernikahan dan perceraian (keduaduanya) penuh kesungguhan, maka dalam menyimpulkan pembahasan ini, penulis juga menyisipkan ada kebutuhan akan pelayanan pastoral yang mendesak kepada pasangan yang hendak bercerai, telah bercerai maupun yang telah menikah kembali.

\footnotetext{
${ }^{49}$ Verkuyl, Etika Kristen: Seksuil, 114

${ }^{50}$ Stott, Isu-isu Global, 430
} 


\section{Pernikahan adalah rancangan Allah}

Allah adalah Pencipta laki-laki dan perempuan sejak semula, dan Dia sendiri yang membentuk lembaga pernikahan. Tujuan-Nya adalah bahwa seksualitas manusia akan mencapai kepenuhannya dalam pernikahan, dan bahwa pernikahan menjadi sebuah kesatuan "menjadi satu daging" yang terpisah dari yang lain (eksklusif), penuh kasih dan seumur hidup. ${ }^{51}$ Olehnya pernikahan adalah komitmen monogami seumur hidup (Mat.19:6; Rm.7:2). Tetapi perceraian melanggar perjanjian tersebut. ${ }^{52}$

Gereja perlu mempersiapkan pernikahan anggotanya dengan baik. Ada kebutuhan pastoral akan persiapan pernikahan. Itu sebabnya, gereja harus menyampaikan pengajaran Alkitab yang menyeluruh tentang pernikahan (pelbagai keterampilan yang diperlukan untuk menyelesaikan konflik hubungan, yang bermanfaat dalam pernikahan dan juga pelbagai aspek kehidupan gereja yang lain). Dalam kotbah, pengajaran atau kelas-kelas katekisasi maupun kelas-kelas bimbingan pranikah gereja harus menjunjung tinggi (menegakkan) kehendak Allah dan norma pernikahan, yakni kesetiaan yang eksklusif, berkomitmen dan seumur hidup. Allah memaksudkan pernikahan sebagai komitmen seumur hidup antara seorang laki-laki dengan seorang perempuan. Perceraian melanggar perjanjian atau ikrar tersebut. Karena itu, perceraian tidak pernah dibenarkan dengan alasan apa pun. Apa yang disatukan Allah, tidak boleh diceraikan oleh manusia (Mat.19:6). Mengikuti pengajaran Tuhan Yesus, gereja berfokus pada dorongan untuk rekonsiliasi antarpasangan, bukan malah mengizinkan perceraian.

Perceraian tidak diperintahkan di bagian mana pun di dalam Alkitab, dan bahkan tidak pernah dianjurkan. Pada dasarnya bagi Tuhan Yesus sangat jelas dan tegas bahwa Ia tidak menganjurkan praktik perceraian dan pernikahan kembali. Ia tetap berpegang teguh (konsisten) pada perkataan-Nya yang mengacu pada Perjanjian Lama, "Karena itu, apa yang telah dipersatukan Allah, tidak boleh diceraikan manusia" (Mat. 19:6 band. Mrk.10:9). Ketika Tuhan Yesus ditanya tentang perceraian, Ia kembali pada kisah penciptaan. Termasuk Paulus dengan menulis 1 Korintus 7:10-11 membahas isu perceraian, ia ingin mencegah warga jemaat di Korintus berdasarkan larangan mutlak Allah yang ia ketahui. Dengan jelas dan tegas Paulus melarang perceraian. Alasan Paulus bahwa Allah memaksudkan pernikahan sebagai ikatan atau komitmen yang permanen, yang berakhir hanya ketika salah satu pasangannya meninggal (Rm.7:1-3; 1 Kor.7:10-11).

\footnotetext{
${ }^{51}$ Ibid.,430

${ }^{52}$ Geisler, Etika Kristen: Pilihan dan Isu Kontemporer, 361
} 
Larangan Tuhan Yesus kepada suami supaya jangan menceraikan isterinya (begitu juga sebaliknya isteri tidak boleh menceraikan suaminya) dapat dimengerti atau dipandang sebagai kesimpulan dan sekaligus penegasan bahwa ikatan pernikahan tidak dapat dibubarkan atau diretakkan. Larangan-Nya untuk bercerai semestinya dimengerti secara absolut. Kesatuan suami isteri yang telah disatukan oleh Allah sebagai Pencipta, tidak boleh dipisahkan oleh manusia. Jawaban Tuhan Yesus atas pertanyaan orang Farisi: apakah seorang suami diperbolehkan menceraikan isterinya adalah "tidak" (baik untuk seorang suami maupun seorang isteri). Perceraian secara absolut dilarang dengan alasan bahwa Allah sendirilah yang mempersatukan kedua pasangan. Tuhan Yesus merangkumkan argumentasi-Nya dengan mengatakan bahwa "Apa yang telah dipersatukan Allah, tidak boleh diceraikan manusia" (Mat. 19:6; Mrk.10:9).

Namun jika terjadi perzinahan, sehingga tidak dapat diperbaiki kembali keadaannya, hanya hidup "berpisah" sajalah yang diperbolehkan bukan perceraian. Penulis sependapat dengan apa yang diungkapkan oleh John Stott bahwa kalau pun diizinkan (berpisah bahkan bercerai) dalam Alkitab, tetap merupakan suatu kemerosotan yang menyimpang dari norma semula Allah. ${ }^{53}$ Dengan demikian, perzinahan itu tidak secara otomatis atau bukanlah suatu keharusan-mengarah kepada perceraian, melainkan lebih menjadi kesempatan berdamai dan kesempatan untuk saling mengampuni. Hendaklah suami atau isteri yang jatuh ke dalam dosa zinah itu menyesalinya dan memohan pengampunan kepada Tuhan dan pasangannya. Di dalam perjuangan untuk mengampuni pasangannya itu pun ada sumber kekuatan yang tidak akan habis. Tuhan Yesuslah sumber kekuatan yang tidak akan habis itu untuk dapat melanjutkan permulaan yang baru sampai maut memisahkan mereka.

Penting suami isteri saling memaafkan agar setiap konflik yang dihadapi dalam rumah tangganya tidak berlanjut kepada hal-hal yang lebih buruk. Maidiantius mengatakan ketika kita memaafkan kesalahan seseorang, saat itu juga kita berdamai dengan seseorang yang membuat kita jengkel, marah dan kecewa. Dan janganlah pernah menyimpan kekesalan dan kemarahan terhadap pasangan kita sampai berhari-hari, melainkan berinisiatif untuk membicarakan dan memaafkan guna mencapai titik temu kesepakatan jika mengalami konflik dengan pasangan kita. Dengan saling memaafkan akan membuat keutuhan semakin kuat dan kebahagiaan dipulihkan kembali. ${ }^{54}$

Di dalam 1 Korintus 7:10-11 bisa ditemukan sebuah ajaran Tuhan Yesus yang menawarkan inisiatif yang mengubah yang dapat mencegah perceraian. Paulus mengatakan

\footnotetext{
${ }^{53}$ Stott, Isu-isu Global, 430

${ }^{54}$ Maidiantius “Konflik Dalam Pernikahan” Jurnal Jaffray Volume 3, No. 1, Juni 2005: 25
} 
demikian: "Kepada orang-orang yang telah kawin aku-bukan aku, tetapi Tuhanperintahkan, supaya seorang isteri tidak boleh berpisah dari suaminya. Dan jikalau ia berpisah, ia harus hidup tanpa suami atau berdamai dengan suaminya. Dan seorang suami tidak boleh menceraikan isterinya". Paulus memberikan semacam konsekuensi kepada orang Kristen tertentu yang hendak bercerai, yaitu bahwa ia sesudah perceraiannya lebih baik tetap sebagai orang yang tidak menikah.

Paulus di sini menawarkan apa yang ia nyatakan sebagai perkataan Tuhan Yesus bahwa pasangan tidak boleh berpisah satu dari yang lain; tetapi jika mereka berpisah, mereka harus "hidup tanpa suami/isteri atau berdamai" dengan pasangannya itu. Dengan kata lain, jika perpisahan sudah terjadi, jangan bercerai, jika perceraian telah terjadi, jangan menikah kembali. Sebaliknya mereka diminta untuk mencari perdamaian sementara masih ada kesempatan. Ini merupakan sebuah pegangan ajaran yang eksplisit dari Tuhan Yesus yang dilaporkan oleh Paulus, yang memandatkan inisiatif yang mengubah untuk menyembuhkan pernikahan yang mengalami cedera. ${ }^{55}$

Paulus nyata dengan cepat melepaskan harapannya bahwa masih dapat terjadi perdamaian atau rekonsiliasi di antara kedua pasangan yang bersangkutan, meskipun pada dasarnya ia menerima keputusan perpisahan itu dari seorang warga jemaat. Tidak ada intimidasi dari pihaknya untuk membuat isteri tersebut kembali hidup bersama-sama dengan suaminya. Itu adalah nasihat dan imbauan Paulus untuk berdamai sebab Allah menginginkan perdamaian di antara pasangan.

Ditambahkan oleh Ruth Schafer dan Freshia Aprilyn Ross, bahwa "hidup berdamai adalah hal yang dinilai Paulus lebih tinggi daripada ikatan pernikahan". ${ }^{56}$ J. Verkuyl juga menegaskan bahwa perbuatan zinah itu tidak boleh menjadi alasan untuk bercerai, tetapi mereka terpanggil untuk saling mengampuni dan mulai lagi dengan permulaan yang baru. ${ }^{57}$ Seperti sikap Paulus yang berusaha menciptakan perdamaian atau rekonsiliasi dalam pernikahan, demikian jugalah semestinya sikap gereja di dalam pelayanan pastoralnya menghadapi warganya yang hendak bercerai, yakni tidak melepaskan pengharapan akan terjadinya rekonsiliasi dalam pernikahan.

Di sinilah pentingnya gereja menyampaikan pengajaran yang jelas dan praktis tentang tugas dan cara pengampunan karena perdamaian atau rekonsiliasi merupakan esensi kekristenan. Ketika orang Farisi menanyakan kepada Tuhan Yesus tentang alasan perceraian,

\footnotetext{
${ }^{55}$ Stassen dan Gushee, Etika Kerajaan : Mengikut Yesus dalam Konteks Masa Kini, 368

${ }^{56}$ Schafer dan Ross, Bercerai Boleh atau Tidak? Tafsiran Terhadap Teks-teks Perjanjian Baru, 181

${ }^{57}$ Verkuyl, Etika Kristen: Seksuil, 114
} 
Ia bahkan minta mereka merujuk pada lembaga pernikahan yang awal. Tujuan semula Allah adalah pernikahan, bukan perceraian, dan Injil-Nya adalah Kabar Baik tentang perdamaian atau rekonsiliasi. Penyesalan dan pertobatan mengubah situasi. Diharapkan gereja berusaha lebih aktif dalam pelayanan perdamaian atau rekonsiliasi ini sebagai upaya pencegahan terhadap tindakan perceraian. Bila gereja terlibat aktif dalam pelayanan ini (kegiatan-kegiatan rekonsiliasi), pasti lebih banyak orang yang akan mencari bantuan, dan mencarinya sejak awal, kalau saja mereka tahu di mana mereka boleh datang untuk mendapatkan pertolongan dan nasihat itu.

Sehubungan dengan rencana Allah bagi pernikahan, gereja terpanggil untuk mendamaikan. Gereja harus berusaha melakukan segala sesuatu sekuat tenaga untuk tidak mengizinkan perceraian, melainkan untuk menegakkan standar Allah terhadap pernikahan monogami seumur hidup. Gereja mengizinkan hanya perpisahan saja, bukan perceraian untuk dapat didamaikan kembali kepada rancangan-Nya semula bagi pernikahan. Sebab perceraian bukanlah bagian dari rancangan-Nya atas pernikahan yang dibentuk-Nya. Olehnya, bahwa perceraian adalah gagal memenuhi standar Allah, penghancuran rencana-Nya bagi pernikahan. Hanya dengan kekuatan dari Tuhan Yesus sebagai sumber kasih yang tiada henti untuk membatalkan segala usaha perceraian. Bukan karena perceraian menimbulkan banyak masalah, tetapi karena perceraian tidak sesuai dengan kehendak Allah.

Penyelesaian atau jawaban dari konflik dalam pernikahan, bukanlah meninggalkan pernikahan atau perceraian, melainkan menghadapi masalah tersebut dan memohon kepada Tuhan Yesus untuk berkuasa dan memerintah dalam pernikahan, karena Ia adalah satusatunya yang dapat merobohkan tembok-tembok kekerasan yang memisahkan suami dengan isteri dengan kasih-Nya. Efesus 2:14,"Karena Dialah damai sejahtera kita, yang telah mempersatukan kedua pihak dan yang telah merubuhkan tembok pemisah, yaitu perseteruan. ${ }^{58}$ Jadi, sangat penting sekali proses rekonsiliasi yang dilaksanakan oleh gereja sebagai upaya untuk rujuk kembali dengan pasangannya.

\section{Perceraian dan Pernikahan Kembali Diizinkan tetapi Tidak Diharuskan}

Ada pun alasannya: seorang Kristen dapat menerima kenyataan pembelotan pasangannya yang tidak Kristen, bila pasangannya itu menolak melanjutkan hidup bersamanya. Hanya jika yang tidak Kristen bersikeras untuk meninggalkannya atau melepaskan diri (pembelotan), maka pasangan yang Kristen dalam kondisi "tidak terikat". Pasangan yang Kristen memiliki pilihan untuk melanjutkan kehidupan berumah tangga yang

\footnotetext{
${ }^{58}$ Maidiantius, “Konflik Dalam Pernikahan”, 20
} 
baru dengan menikah lagi. Dalam kasus itu izin perceraian dan pernikahan kembali, maka pernikahan kembali dalam kondisi tidak berzinah atau sah.

Perceraian itu memiliki dampak terhadap nama baik. Orang bercerai biasanya juga akan kehilangan nama baik. Tepat apa yang disarankan Andreas Lumme, gereja harus bertindak bijaksana dan berguna bagi mereka yang bercerai yaitu membantu mereka untuk pendampingan pastoral yang penuh pengertian daripada menjatuhkan nama baik mereka atau menyampaikan kecaman. ${ }^{59}$

Oleh sebab itu, gereja harus mampu menunjukkan kesetaraan untuk bersikap adil dalam memberikan penilaian yang positif terhadap anggota gereja apabila bercerai untuk dapat hidup tenang dan diterima oleh jemaat serta tetap mendapatkan tempat dalam persekutuan jemaat. Bukan sebaliknya mengucilkan mereka. Gereja harus mewujudknyatakan pelayanan pastoral yang bersikap adil dan berbelaskasihan di dalam kehidupan jemaat dalam menghadapi permasalahan anggotanya, termasuk kasus perceraian dan pernikahan kembali. Gereja menciptakan dan memelihara iklim kesetaraan relasional dan keadilan bagi seluruh anggotanya, bukan berfokus pada menjauhi orang-orang tertentu karena berbagai kesalahan di masa lalu (bercerai).

\section{Kesimpulan}

Kesimpulan dalam penelitian ini adalah: Pertama, pernikahan adalah rancangan Allah. Kedua, perceraian tidak diperintahkan di bagian mana pun di dalam Alkitab, dan bahkan tidak pernah dianjurkan. Ketiga, Perceraian dan pernikahan kembali diizinkan tetapi tidak diharuskan.

\section{Kepustakaan}

Al-Amin, Mukayat dan Moearifah, Noeroel "Perkawinan Menurut Islam dan Protestan" Jurnal AL-Hikmah, Vol. 1, No. 2, 2015

Goodall, Wayde I. dan Goodall, Rosalyn R. Marriage \& Family. Malang: Gandum Mas, 2010 Geisler, Norman. Etika Kristen: Pilihan dan Isu Kontemporer. Malang: SAAT, 2010

Lumme, Andreas. "Norma Hukum Agama Katolik Di Bidang Perceraian Dan Konflik Penerapannya Di Pengadilan Bagi Perceraian Suami Istri” Jurnal Hukum Pro Justisia, Vol.25 No.2, April 20017

Maidiantius “Konflik Dalam Pernikahan” Jurnal Jaffray Volume 3, No. 1, Juni 2005

Napel, Henk ten. Jalan yang Lebih Utama Lagi: Etika Perjanjian Baru. Jakarta: BPK Gunung Mulia, 2012

Rosely, Sonya "Putusnya Perkawinan Karena Perceraian (Kajian Berdasarkan Hukum Gereja Bagi Perkawinan Kristen Di Indonesia)" Jurnal Pascasarjana Fakultas Hukum Universitas Brawijaya Malang

Stassen, Glen H dan Gushee, David P. Etika Kerajaan : Mengikut Yesus dalam Konteks Masa Kini. Surabaya: Momentum, 2013

\footnotetext{
${ }^{59}$ Lumme, "Norma Hukum Agama Katolik Di Bidang Perceraian Dan Konflik Penerapannya Di Pengadilan Bagi Perceraian Suami Istri”, 92
} 
Stevanus, Kalis. Cekcok Tapi Sudah Cocok. Yogyakarta: Andi, 2014

Sabdono, Erastus. Perceraian. Jakarta: Rehobot Literature, 2018

Stott, John. Isu-isu Global. Jakarta: Yayasan Komunikasi Bina Kasih, 2015

Schafer, Ruth dan Ross, Freshia Aprilyn. Bercerai Boleh atau Tidak? Tafsiran terhadap Teksteks Perjanjian Baru. Jakarta: BPK Gunung Mulia, 2017

Verkuyl, J. Etika Kristen: Seskuil. Jakarta: BPK Gunung Mulia, 1993

Wright, Christopher. Hidup sebagai Umat Allah: Etika Perjanjian Lama. Jakarta: BPK Gunung Mulia, 1995 